Beata Gavurova,

Ph.D., Associate Professor, Technical University of Kosice,

Kosice, Slovakia

Radovan Bacik,

Ph.D., Associate Professor, University of Presov,

Presov, Slovakia

Richard Fedorko, Ph.D., University of Presov, Presov, Slovakia

Martin Rigelsky, University of Presov, Presov, Slovakia

\title{
ANALYTICAL VIEW OF ONLINE MARKETING TOOLS IN THE DIMENSION OF MARKETING CAMPAIGNS' PERSONALIZATION IN SLOVAKIA
}

The objective of the article is to enrich knowledge about marketing personalization of the optimization of marketing campaigns. In the article, differences in how customers perceive individual tools of marketing communication in the online environment were evaluated. When creating campaigns, only the customer's view of the product (segmentation) is often taken into account. This article recommends some bases depending on campaign optimization variables. From a methodological point of view, a homogeneity analysis was used to analyse the hypotheses that assessed the impact of instruments, as well as the impact depending on identification variables, such as gender, education and social status. Based on the outputs these facts were analysed. A questionnaire was used. (Data collection took place in early 2017). Our research has an application character and, therefore, one of the most attractive findings is in the area of practice, where focusing marketing campaigns on sales support in visual forms was recommended. In the vast majority of cases, the maker of marketing activities focuses on the construction of segments based on assumptions in strong association with the product. We optimize this approach because different customer groups respond differently to different tools and forms of tools and to their mutual combinations. Limitations of applications can be determined depending on the nature of the base file and therefore for countries with a distinctly different structure, the outputs do not have to be valid. Applying the lessons learned from the field of diversification of the impact of individual instruments in the early stages of campaigns can be recommended or in campaigns where there is an explicit problem with the exact determination of customer segments and the optimal tools

Keywords: marketing tools, customer personalization, personalization of marketing communication, optimization of marketing campaigns, Slovak market.

General formulation of the problem. In the vast majority of cases, the creation of marketing activities focuses on the construction of segments based on assumptions in strong association with the product. In creating marketing campaigns is one of the most important things is to correctly choose the tools and the forms of tools. The principle of personalization is embedded in a detailed understanding of the customer. The tools and their forms should also be chosen based on customer request. To what extent can we consider the impact of individual communication mix tools to be homogeneous? To what extent can we 
consider the impact of various forms of communication mix tools to be homogeneous? The answers to these questions define, on the one hand, the diversity and, on the other hand, the optimization of the tools and their forms for the individual groups.

Introduction. Kotler and Keller (2012, p. 5) define marketing as the concise phrase "meeting needs profitably". According to these ideas, we find an embedded form of modern marketing in the interaction of primarily satisfied customer needs. Thousands of businesses have taken this idea for their own and satisfying customer needs. The difference between those successful and unsuccessful ones is that successful businesses know how to "agree" with the customer.

Marketing communication can be a tool of differentiation, which in practice means building a competitive advantage (Porter, 1985). Business responds to all environmental stimuli from external interest groups to individuals. These are the key factors of successful organization management (Bednarčík, 2010, Štefko et al. 2014, Mura et al. 2015). Optimizing "marketing efforts", maximizing efficiency in traditional or online marketing and other methods, models, techniques have been devised to move forward the communication. Among the best known we can find Kotler's model (2007), which includes the identification, the collection and evaluation of alternatives and the post-purchasing behaviour. All models are effective. The fact is that different types of people influence marketing tools and their forms differently. Foret (2006) states that marketing communication going on in the online environment brings great opportunities. Janouch (2010) who in his publication concretizes the possibilities of online marketing, also confirms this idea. Every year we learn about the areas of online marketing efficiency. Kwon, Ha and Kowal (2017), enhance the effectiveness of product and service customization. They talk about online platforms where the customer can customize the goods. Meeting customer needs is one of the driving ideas of marketing, personalizing goods for a customer is definitely a positive step forward. The importance of personalization is not negligible even when communicating with the customer.

Literature review. The experiment conducted by Li and Liu (2017) in the perception of personalized and impersonalized reports showed a clear superiority of personalized messages. Recently, personalization in marketing communication strategies has become a subject of research by few experts. Authors like Lanvin et al. (2018) Watróbski et al. (2016) claim that customizing in e-commerce increases sales by improving the perception of the site quality by customers. In addition, they point to the relationship between personalization and loyalty, which is rarely attributed to an increased frequency of purchases. Jung Lee, Park (2009) have done research on personalization and on its dynamics in clothing stores, where personalization has proven to be a very useful tool for developing customer relationships. Xu, Zou, Wang (2006) highlight the importance of demographic variables in terms of the differences in customer buying patterns. Personalization also has its place in the design of marketing campaigns. This concept has become familiar with the campaigning process. Many types of research of varying depth have demonstrated the "prosperity" of introducing the personalization principle into campaigning. A very elegant personalization was applied by McDarby, O'Hora, O'Shea and Byrne, (2018) who examined children's habits when choosing healthy and unhealthy drinks and personified their personality when they chose a drink. Tran (2017), led his research to personalization and segmentation in Facebook and his research confirms the importance and power of personalized advertisements. This issue was also addressed by Matic, Pielot and Oliver, (2017) who demonstrated the "charm" of personalization on highly personalized advertisements. Kim, Ammeter, (2018) compared two consecutive modern generations of customers. Personalization was one of the six elements in which differences were manifested. Therefore, it would be a fundamental mistake to underestimate the principles and elements of personalization in campaigning. There are many other authors who deal with the issue of personalization in marketing, such as Xiao and Benbasat (2011), Makris, Siaterlis and Vikatos, (2017), Haim, Graefe and Brosius (2018), Grancay et al. (2015) or Sahni, Wheeler and Chintagunta (2016). As has been demonstrated in the previous sections, personalization plays a very important role in modern marketing. When designing many online marketing 
campaigns, the question of choosing an appropriate tool and making it more specific is considered secondary or, at best, intuitive (Schwarzl and Grabowska, 2015). The customer should choose an instrument according to modern marketing concepts. The following are aimed at verifying the homogeneity of the impact of different forms of communication attributed to customers.

Research methodology. The primary objective of this research is to evaluate the differences between the perceptions of individual instruments and their forms. The following figure describes the principle that if we know the customer, we knew a lot about the impact of specific tools and forms of tools by analogizing the most optimal campaign. This method helps to optimize resources by maximizing the efficiency of the campaign. We should not take it as a necessity but rather as determining the location and importance of the campaign to understand the customer.

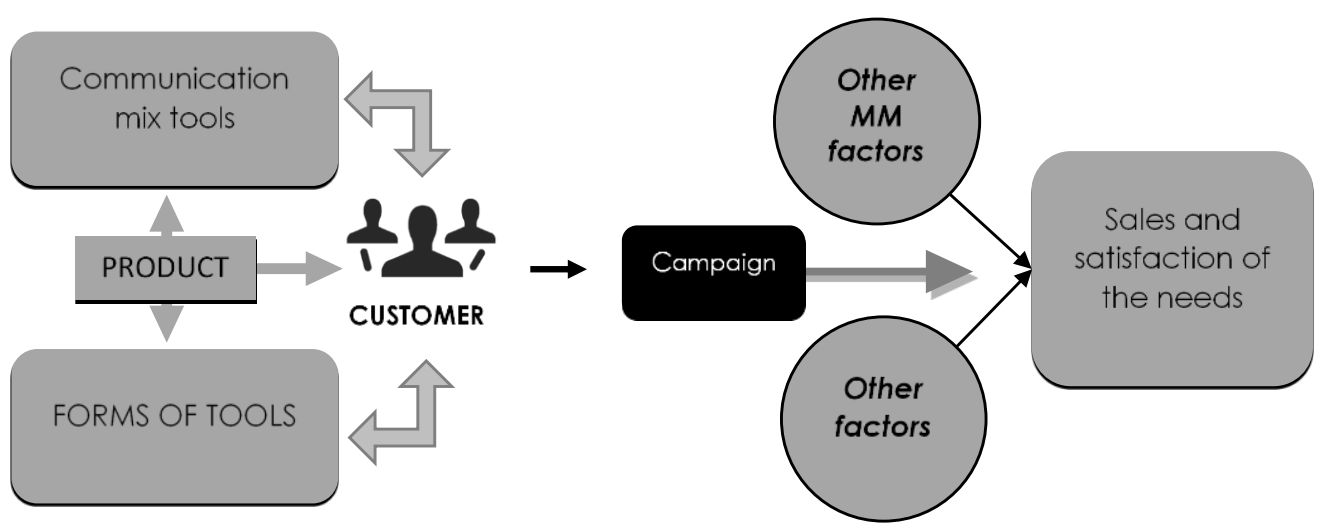

Figure 1 - Creating a marketing campaign (own elaboration)

As shown in the previous Figure 1, our efforts are inherently linked to the sale of products (goods/services). This sale is analogous to communication; we will be devoted to the dimension of tools and their forms. In communication, the subject of marketing, and therefore the social interaction at the end materializes. Knowing our customer (in terms of demographic variables) is extremely important for a successful campaign. The actual sale of products that meet the requirements of satisfaction is defined in addition to the communication campaign by other elements of the marketing mix, e.g. packaging, prices as well as other factors and preferences. Our work focuses exclusively on the communication component of a personalized marketing campaign.

In the analysis leading to the fulfilment of the stated objective we present the following research questions with the main hypotheses:

R.Q.I: To what extent can we consider the impact of individual communication mix tools to be homogeneous?

H.1.a: We expect a significant difference in the impact of certain communication mix tools.

H.1.b: We assume a significant degree of difference between the various communication mix tools depending on the category of gender.

H.1.c: We expect a significant degree of difference between the certain communication mix tools, depending on the category of the highest achieved education.

H.1.d: We expect a significant degree of difference between the various communication mix tools depending on the category of social status.

R.Q.II: To what extent can we consider the impact of the various forms of communication mix tools to be homogeneous? 
H.2.a: We expect a significant difference in the impact of certain forms of communication mix tools.

H.2.b: We expect a significant degree of difference between different forms of communication mix tools, depending on the category of the gender.

H.2.c: We expect a significant degree of difference in different forms of communication mix instruments, depending on the category of the highest achieved education.

H.2.d: We expect a significant degree of difference in the different forms of communication mix tools depending on the category of social status.

\section{Methodology for data collection, description of the methods of investigation}

As we can assume from these hypotheses, our research can be characterized as primary, applied and interdisciplinary. We carried out the research in the form of selection based on the availability. We distributed the questionnaires on social sites and we also used e-mails (own personal databases). In the research, we collected 244 questionnaires. Data collection took place in early 2017. All observations were carried out in Slovakia. We divided the questionnaire (https://goo.gl/forms/7hORqmRG5FtXZMGS2) to find the measurement variable and the identification variable. The measurement variables examined how the respondents felt to be affected by advertising, sales promotion, events, PR and direct marketing in the online environment. We have also examined the impact of the forms we have specified e.g. text, interactive, multimedia, visual, auditory, social sites, (RSS, etc.). For both tools and forms of tools, we have provided specific examples for better visualization of the elements. Tools and forms have been selected based on the theory presented by Janouch (2010). Likert scale determined the impact level. The identifying variables were gender, highest education and social status. In addition, for descriptive statistics and frequency analysis, we used non-parametric homogeneity tests to guide us towards achieving our objective. In the analysis of two categories of variables, we used the Mann-Whitney $U$ test and for three or more categories of the analysed variables the Kruskal-Wallis $\mathrm{H}$ test.

Frequency analysis of survey variables. The following Figure 2 tells us about the ratios of the acquired outputs of gender, education and social status variables. The outputs of the variable, in particular, reflect the proportionality of the base file ratio.
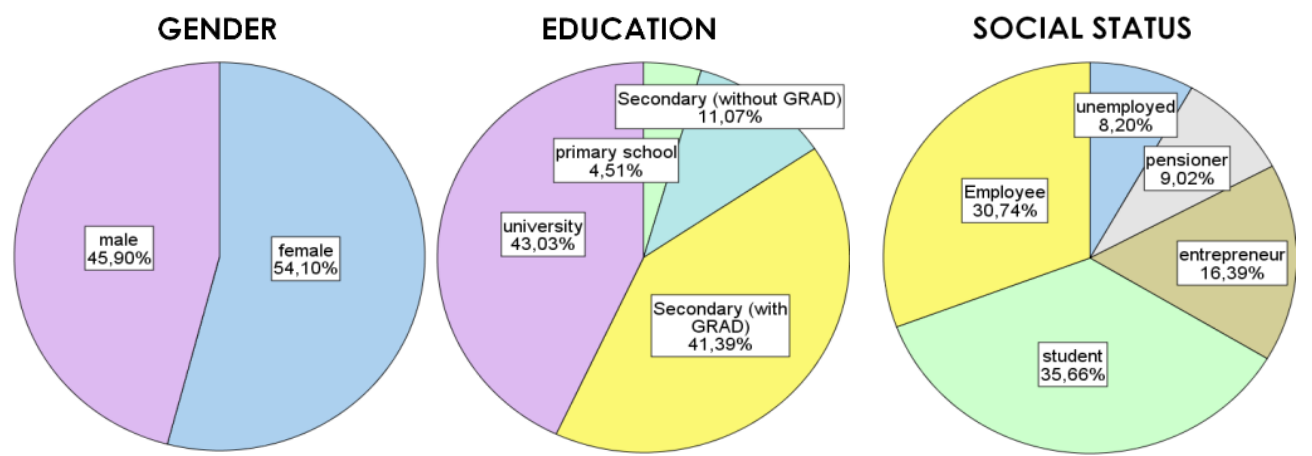

Figure 2 - Output of frequency analysis of identification variables (own elaboration)

Dependent variables are also part of the research. We analysed them in the following tables. The tables are enriched with a column view that symbolizes the category output to $100 \%$. The following table provides an overview of the achieved results in the questionnaire survey in the dimension of online marketing tools. Individual instruments were defined in terms of the Slovak Republic. These are general outcomes without any specification of the market segment and the customer. 
Table 1 - Online marketing tools - Impact Mean (own elaboration)

\begin{tabular}{|c|c|c|c|}
\hline & & Count & $\mathrm{N}$ of $\%$ \\
\hline \multirow{5}{*}{ ADVERTISING } & does not affect & 25 & 10.25 \\
\hline & rather it does not affect & 58 & 23.77 \\
\hline & I can not say & 10 & 4.10 \\
\hline & rather affects & 65 & 26.64 \\
\hline & affects & 86 & 35.25 \\
\hline \multirow{5}{*}{$\begin{array}{l}\text { SALES } \\
\text { PROMOTION }\end{array}$} & does not affect & 35 & 14.34 \\
\hline & rather it does not affect & 26 & 10.66 \\
\hline & I can not say & 21 & 8.61 \\
\hline & rather affects & 56 & 22.95 \\
\hline & affects & 106 & 43.44 \\
\hline \multirow{5}{*}{ ONLINE EVENT } & does not affect & 45 & 18.44 \\
\hline & rather it does not affect & 52 & 21.31 \\
\hline & I can not say & 20 & 8.20 \\
\hline & rather affects & 77 & 31.56 \\
\hline & affects & 50 & 20.49 \\
\hline \multirow{5}{*}{$\begin{array}{l}\text { PUBLIC } \\
\text { RELATIONS }\end{array}$} & does not affect & 50 & 20.49 \\
\hline & rather it does not affect & 31 & 12.70 \\
\hline & I can not say & 31 & 12.70 \\
\hline & rather affects & 91 & 37.30 \\
\hline & affects & 41 & 16.80 \\
\hline \multirow{5}{*}{$\begin{array}{l}\text { DIRECT } \\
\text { MARKETING }\end{array}$} & does not affect & 30 & 12.30 \\
\hline & rather it does not affect & 41 & 16.80 \\
\hline & I can not say & 20 & 8.20 \\
\hline & rather affects & 61 & 25.00 \\
\hline & affects & 92 & 37.70 \\
\hline
\end{tabular}

From a first glance, we see that the vast majority of instruments dominate in the most positive assessment. We see the fluctuations in online events and PR where they were placed in the second highest position. As described in the previous Table 1, the tool outputs are examined and we discuss their forms as shown in the following Table 2.

In the first four forms, we can see that the attributed influence is unequivocally placed in the most positively offered response option - thus influencing it. It was about the tools of visual, multimedia, interactive and textual character. "Worst outputs" are in the form of others (RSS, etc.) and in auditory forms. Social websites, as a specific form, are surprisingly achieving very positive outcomes.

Analysis of hypotheses. The following section was devoted to the analytical examination of the hypotheses listed in the methodological part of this article. This part is conceived with respect to hypothesis analysis, and therefore the analysis of each hypothesis is another part.

Tools in general. In the following section, we offer the results of the analysis of the homogeneity of the impact of the individual tools used in marketing campaigns.

H.1.a: We expect a significant difference in the impact of certain communication mix tools.

We investigated the previous hypothesis by the Kruskal-Wallis $\mathrm{H}$ nonparametric method. The decision mechanism is based on asymptotic significance and on the p-value over the hypothesis:

$\mathrm{HO}$ : There are no significant differences between the analysed variables.

$\mathrm{H1}$ : There are significant differences between the analysed variables. 
Table 2 - Forms of online marketing tools - Impact Mean (own elaboration)

\begin{tabular}{|c|c|c|c|}
\hline & & Count & $\mathrm{N}$ of $\%$ \\
\hline \multirow{5}{*}{ Text } & does not affect & 30 & 12.30 \\
\hline & rather it does not affect & 41 & 16.80 \\
\hline & I cannot say & 21 & 8.61 \\
\hline & \begin{tabular}{|l|} 
rather affects \\
\end{tabular} & 56 & 22.95 \\
\hline & affects & 96 & 39.34 \\
\hline \multirow{5}{*}{ Interactive } & does not affect & 20 & 8.20 \\
\hline & rather it does not affect & 21 & 8.61 \\
\hline & I cannot say & 15 & 6.15 \\
\hline & rather affects & 67 & 27.46 \\
\hline & affects & 121 & 49.59 \\
\hline \multirow{5}{*}{ Multimedia } & does not affect & 15 & 6.15 \\
\hline & rather it does not affect & 22 & 9.02 \\
\hline & I cannot say & 30 & 12.30 \\
\hline & rather affects & 57 & 23.36 \\
\hline & affects & 120 & 49.18 \\
\hline \multirow{5}{*}{ Vizual } & does not affect & 15 & 6.15 \\
\hline & \begin{tabular}{|l|} 
rather it does not affect \\
\end{tabular} & 16 & 6.56 \\
\hline & I cannot say & 20 & 8.20 \\
\hline & rather affects & 62 & 25.41 \\
\hline & affects & 131 & 53.69 \\
\hline \multirow{5}{*}{ Audial } & does not affect & 30 & 12.30 \\
\hline & rather it does not affect & 32 & 13.11 \\
\hline & \begin{tabular}{|l|} 
I cannot say \\
\end{tabular} & 36 & 14.75 \\
\hline & rather affects & 81 & 33.20 \\
\hline & affects & 65 & 26.64 \\
\hline \multirow{5}{*}{ Social site } & does not affect & 20 & 8.20 \\
\hline & rather it does not affect & 30 & 12.30 \\
\hline & I cannot say & 21 & 8.61 \\
\hline & rather affects & 72 & 29.51 \\
\hline & affects & 101 & 41.39 \\
\hline \multirow{5}{*}{ Others } & does not affect & 40 & 16.39 \\
\hline & rather it does not affect & 36 & 14.75 \\
\hline & I cannot say & 60 & 24.59 \\
\hline & rather affects & 68 & 27.87 \\
\hline & affects & 40 & 16.39 \\
\hline
\end{tabular}

Based on the output of $\mathrm{p}$, we recommend not rejecting the alternative $\mathrm{H} 1$ hypothesis. There are significant differences between the analysed impact variables. We can see the highest impact was measured by Sales promotion, the smallest one on PR.

Tools in the dimension of gender. In the following section, we offer the results of the homogeneity analysis of tools used in marketing campaigns between women and men.

H.1.b: We assume a significant degree of difference between the various communication mix tools depending on the category of gender. 
Table 3 - Hypothesis test H.1.a + definition of impact (own elaboration)

\begin{tabular}{|l|c|}
\hline \multicolumn{2}{|c|}{ Test Statistics } \\
\hline Chi-Square & 39.770 \\
\hline df & 4 \\
\hline Asymp. Sig. & .000 \\
\hline
\end{tabular}

\begin{tabular}{|l|c|c|}
\hline \multicolumn{1}{|c|}{ Tools } & Ranks $\%$ & Mean rank \\
\hline ADVERTISING & 20.94 & 639.27 \\
\hline SALES PROMOTION & 22.44 & 685.09 \\
\hline ONLINE EVENT & 17.64 & 538.56 \\
\hline PUBLIC RELATIONS & 17.56 & 535.95 \\
\hline DIRECT MARKETING & 21.41 & 653.63 \\
\hline
\end{tabular}

We investigated the previous hypothesis by the non-parametric Mann-Whitney $U$ test. The decision mechanism is based on asymptotic significance and on the p-value over the hypothesis:

HO: There are no significant differences in the degree of impact between the gender categories.

$\mathrm{H} 1$ : There are significant differences in the degree of impact between the gender categories.

Table 4 - Hypothesis test - H.1.b (own elaboration)

\begin{tabular}{|l|c|c|c|c|c|}
\hline & Advertising & Sales & Online event & Public & Direct \\
\hline Mann-Whitney U & 6038.000 & 6791.000 & 6046.500 & 6576.000 & 6773.500 \\
\hline Asymp. Sig. (2-tailed) & .010 & .249 & .012 & .124 & .241 \\
\hline
\end{tabular}

Based on the output of the $\mathrm{p}$-value, we recommend not rejecting the alternative $\mathrm{H} 1$ hypothesis in the Advertising and Online event variables. Table 5 shows the impact level.

Table 5 - Forms of tools (Gender) - evaluation (own elaboration)

\begin{tabular}{|l|l|c|c|}
\hline \multicolumn{2}{|c|}{ Gender } & N & Mean Rank \\
\hline \multirow{2}{*}{ Advertising } & female & 132 & 132.76 \\
\cline { 2 - 4 } & male & 112 & 110.41 \\
\hline \multirow{2}{*}{ Sales promotion } & female & 132 & 127.05 \\
\cline { 2 - 4 } & male & 112 & 117.13 \\
\hline \multirow{2}{*}{ Online event } & female & 132 & 112.31 \\
\cline { 2 - 4 } & male & 112 & 134.51 \\
\hline \multirow{2}{*}{ Public relations } & female & 132 & 116.32 \\
\cline { 2 - 4 } & male & 112 & 129.79 \\
\hline \multirow{2}{*}{ Direct marketing } & female & 132 & 117.81 \\
\cline { 2 - 4 } & male & 112 & 128.02 \\
\hline
\end{tabular}

The previous Table 5 exactly determines the impact outputs. As indicated, the difference was confirmed by the "Advertising" variable for women and by the "Events" for men.

Tools in the dimension of education. In the following section, we offer the results of the analysis of the homogeneity on the impact of the tools used in marketing campaigns among the groups of customers with the achieved primary education, secondary education with or without a school leaving examination and higher education.

H.1.c: We expect a significant degree of difference between the certain communication mix tools, depending on the category of the highest achieved education.

We investigated the previous hypothesis by the Kruskal-Wallis $\mathrm{H}$ nonparametric method. The decision mechanism is based on asymptotic significance and on the p-value over the hypothesis:

$\mathrm{H}_{0}$ : There are no significant differences in the degree of impact between the categories of education. 
$\mathrm{H}_{1}$ : There are significant differences in the degree of impact between the categories of education.

Table 2 - Hypothesis test - H.1.c (own elaboration)

\begin{tabular}{|l|c|c|c|c|c|}
\hline & Advertising & Sales & Online & Public & Direct \\
\hline Chi-Square & 6.174 & 4.056 & 6.238 & 3.333 & 11.386 \\
\hline $\mathrm{df}$ & 3 & 3 & 3 & 3 & 3 \\
\hline Asymp. Sig. & .103 & .255 & .101 & .343 & .010 \\
\hline
\end{tabular}

Based on the $\mathrm{p}$ output, we recommend not rejecting the alternative $\mathrm{H} 1$ hypothesis in the direct marketing variable. Thus, for instruments, the adaptation to the customer with a certain education appears to be unnecessary. In this case, personalization should only make sense in direct marketing. Figure 3 shows the impact level.

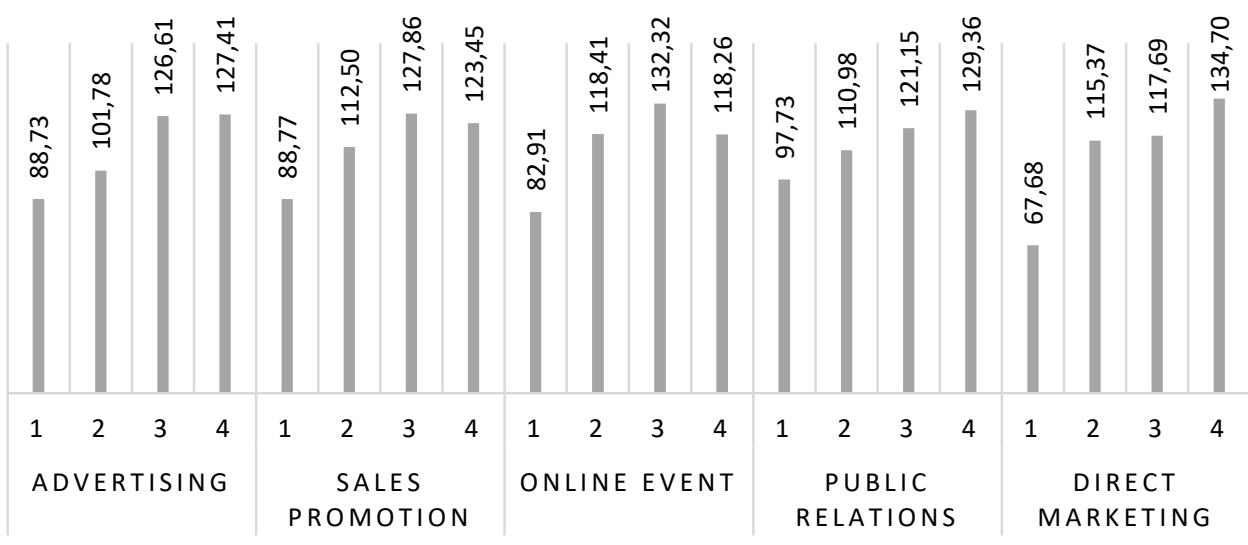

*1 - Primary school, 2 - Secondary (without graduation), 3 - Secondary (with graduation), 4 - University

Figure 3 - Forms of tools (Education) - evaluation (own elaboration)

We have deduced the only significant difference in direct marketing. Our output in this category is not recommended for customers with the level of primary education.

Tools in the dimension of social status. In the following, we offer the results of the analysis of the homogeneity of the impact of the tools used in the marketing campaigns among the customer groups in the social status category.

H.1.d: We expect a significant degree of difference between the various communication mix tools depending on the social status category.

Table 3 - Hypothesis test - H.1.d (own elaboration)

\begin{tabular}{|l|c|c|c|c|c|}
\hline & Advertising & Sales & Online event & Public & Direct \\
\hline Mann-Whitney U & 6038.000 & 6791.000 & 6046.500 & 6576.000 & 6773.500 \\
\hline Asymp. Sig. (2-tailed) & .010 & .249 & .012 & .124 & .241 \\
\hline
\end{tabular}

We investigated the previous hypothesis by the Kruskal-Wallis $\mathrm{H}$ nonparametric method. The decision mechanism is based on asymptotic significance and on the $p$-value over the hypothesis:

$\mathrm{H}_{0}$ : There are no significant differences in the degree of impact between the categories of social status.

$\mathrm{H}_{1}$ : There are significant differences in the degree of impact between the categories of social status. 
Based on the output of the $\mathrm{p}$-value, we recommend not rejecting the alternative $\mathrm{H} 1$ hypothesis in sales promotion, online event, PR and direct marketing variables. In the above-mentioned tools, the adjustment of a particular form of women and a particular form of men is meaningful. Figure 4 shows the impact level.

As we can see, a significant difference has occurred in several instruments in the category of social status. The lowest level is attributed to the unemployed. This level may be a secondary outcome of the actual impact of unemployment on purchasing preferences. We support retirees and students in promoting sales among the most prominent categories. In case of events, PR and direct marketing, we support both retirees and entrepreneurs.

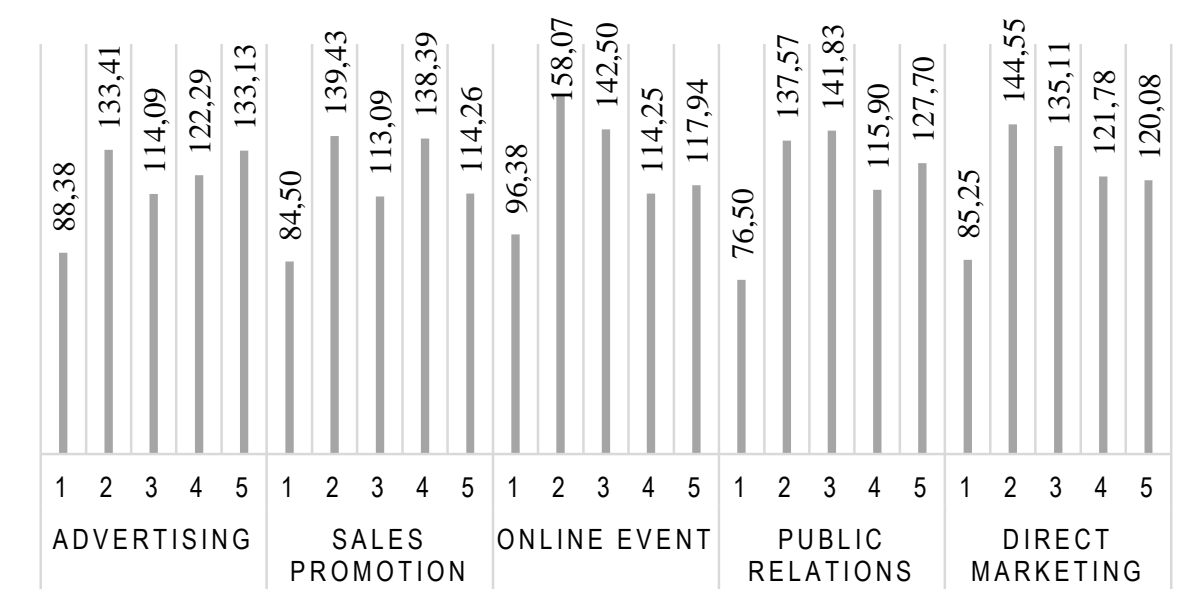

*1 - Unemployed, 2 - Pensioner, 3 - Entrepreneur, 4 - Student, 5 - Employee

Figure 4 - Forms of tools (Social status) - evaluation (own elaboration)

Forms of tools in general. In the following section, we offer the results of the analysis of the homogeneity of the impact of the individual forms of tools used in marketing campaigns.

H.2.a: We expect a significant difference in the impact of certain forms of communication mix tools.

Table 4 - Hypothesis test H.2.a + definition of impact (own elaboration)

\begin{tabular}{|l|c|}
\hline Test Statistics & 122.193 \\
\hline Chi-Square & 6 \\
\hline df & .000 \\
\hline Asymp. Sig.
\end{tabular}

\begin{tabular}{|l|c|c|}
\hline Tools & Ranks \% & Mean Rank \\
\hline Text & 13.71 & 820.15 \\
\hline Interactive & 16.04 & 959.72 \\
\hline Multimedia & 15.87 & 949.44 \\
\hline Vizual & 16.75 & 1001.83 \\
\hline Audial & 12.49 & 747.13 \\
\hline Social site & 14.80 & 885.26 \\
\hline Others & 10.33 & 617.98 \\
\hline
\end{tabular}

We investigated the previous hypothesis through the Kruskal-Wallis $\mathrm{H}$ nonparametric method. The decision mechanism is based on asymptotic significance and on the $p$-value over the hypothesis: 
$\mathrm{H}_{0}$ : There are no significant differences between the analysed variables.

$\mathrm{H}_{1}$ : There are significant differences between the analysed variables.

Based on the output $\mathrm{p}$-value, we recommend not rejecting the alternative $\mathrm{H} 1$ hypothesis. There are significant differences between the analysed impact variables. The highest mean of attributed influence can be seen in "Visual".

Forms of tools in the dimension of gender. In the following section, we offer the results of the analysis of the homogeneity of the impact of the tools used in the marketing campaigns between women and men.

H.2.b: We expect a significant degree of difference between different forms of communication mix tools, depending on the category of the gender.

Table 5 - Hypothesis test - H.2.b (own elaboration)

\begin{tabular}{|l|c|c|c|c|c|c|c|}
\hline & Text & Interactive & Multimedia & Visual & Audial & Social site & Others \\
\hline Mann-Whitney U & 6394.5 & 6227.5 & 5852.0 & 6606.0 & 7239.0 & 6542.5 & 6944.0 \\
\hline Asymp. Sig. (2-tailed) & .058 & .022 & .003 & .116 & .774 & .103 & .403 \\
\hline
\end{tabular}

We investigated the previous hypothesis by the non-parametric Mann-Whitney $U$ test. The decision mechanism is based on asymptotic significance and on the $p$-value over the hypothesis:

$\mathrm{H}_{0}$ : There are no significant differences in the degree of impact between the gender categories.

$\mathrm{H}_{1}$ : There are significant differences in the degree of impact between the gender categories.

\begin{tabular}{|c|c|c|c|}
\hline & Gender & $\mathrm{N}$ & Mean \\
\hline \multirow{2}{*}{ Text } & female & 132 & 130.06 \\
\hline & male & 112 & 113.59 \\
\hline \multirow{2}{*}{ Interactive } & female & 132 & 131.32 \\
\hline & male & 112 & 112.10 \\
\hline \multirow{2}{*}{ Multimedia } & female & 132 & 110.83 \\
\hline & male & 112 & 136.25 \\
\hline \multirow{2}{*}{ Visual } & female & 132 & 128.45 \\
\hline & male & 112 & 115.48 \\
\hline \multirow{2}{*}{ Audial } & female & 132 & 121.34 \\
\hline & male & 112 & 123.87 \\
\hline \multirow{2}{*}{ Social site } & female & 132 & 128.94 \\
\hline & male & 112 & 114.92 \\
\hline \multirow{2}{*}{ Others } & female & 132 & 119.11 \\
\hline & male & 112 & 126.50 \\
\hline
\end{tabular}

Based on the output of the $\mathrm{p}$-value, we recommend not rejecting the alternative $\mathrm{H} 1$ hypothesis in the interactive and multimedia variables. In the above-mentioned forms of tools, the adjustment of a particular form of women and a particular form of men is meaningful. The following table shows the impact level.

Based on the output of the $\mathrm{p}$-value, we recommend not rejecting the alternative $\mathrm{H} 1$ hypothesis in the interactive and multimedia variables. In the above-mentioned forms of tools, the adjustment of a particular form of women and a particular form of men is meaningful. The following table shows the impact level.

Significant differences in influence were reflected in the area of interactive tools for women and multimedia for men. Other forms of instruments were not statistically significant under the influence of 
gender.

Forms of tools in the dimension of education. In the following section, we offer the results of the analysis of the homogeneity of the impact of the tools used in marketing campaigns among the groups of customers with the achieved primary education, secondary education with or without a school leaving examination and higher education.

H.2.c: We expect a significant degree of difference in different forms of communication mix instruments, depending on the category of the highest achieved education.

Table 7 - Hypothesis test - H.2.c (own elaboration)

\begin{tabular}{|l|c|c|c|c|c|c|c|}
\hline & Text & Interactive & Multimedia & Visual & Audial & Social site & Others \\
\hline Chi-Square & 7.986 & 10.124 & 5.776 & 16.548 & 4.371 & 9.027 & 2.465 \\
\hline df & 3 & 3 & 3 & 3 & 3 & 3 & 3 \\
\hline Asymp. Sig. & .046 & .018 & .123 & .001 & .224 & .029 & .482 \\
\hline
\end{tabular}

The previous hypothesis was investigated through the Kruskal-Wallis $\mathrm{H}$ nonparametric method. The decision mechanism is based on asymptotic significance, the p-value over the hypothesis:

$\mathrm{H}_{0}$ : There are no significant differences in the level of impact between the categories of education.

$H_{1}$ : There are significant differences in the level of impact between the categories of education.

Based on the p output, we recommend rejecting the $\mathrm{H} 1$ alternative hypothesis in variables of multimedia, auditing and other forms of marketing tools. These forms of tools can be used in the categories of education. In other cases, customization of the tool would make sense to a customer with a certain level of education. Figure 5 visualizes the impact of tools.

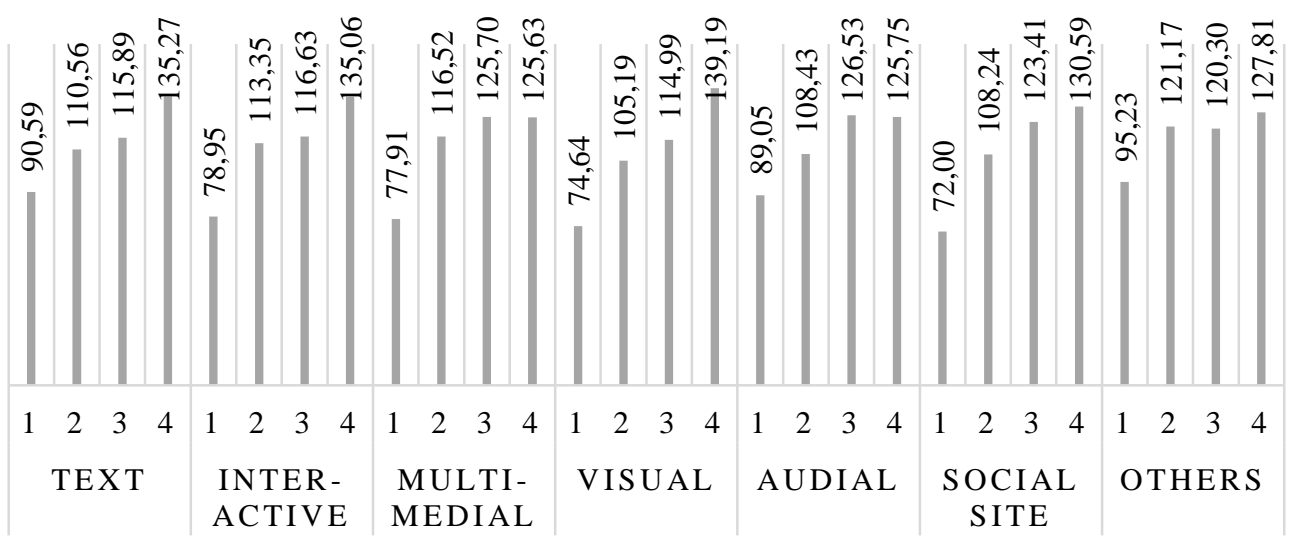

*1 - Primary school, 2 - Secondary (without graduation), 3 - Secondary (with graduation), 4 - University

Figure 5 - Forms of tools (Education) - evaluation (own elaboration)

Differences occurred in text form, where the lowest output is at primary school and the highest output is in case of the higher education. In interactive and in all other instruments with significant differences, the output is similar.

Forms of tools in the dimension of social status. In the following section, we offer the results of the analysis of the homogeneity of the impact of the tools used in the marketing campaigns between customer groups in the category of social status.

H.2.d: We expect a significant degree of difference in the different forms of communication mix tools 
depending on the category of social status.

Table 8 - Hypothesis test - H.2.d (own elaboration)

\begin{tabular}{|l|c|c|c|c|c|c|c|}
\hline & Text & Interactive & Multimedia & Visual & Audial & Social site & Others \\
\hline Chi-Square & 13.055 & 16.481 & 36.083 & 23.331 & 35.402 & 16.551 & 21.554 \\
\hline df & 4 & 4 & 4 & 4 & 4 & 4 & 4 \\
\hline Asymp. Sig. & .011 & .002 & .000 & .000 & .000 & .002 & .000 \\
\hline
\end{tabular}

We investigated the previous hypothesis by the Kruskal-Wallis $\mathrm{H}$ nonparametric method. The decision mechanism is based on asymptotic significance and on the $p$-value over the hypothesis:

$\mathrm{H}_{0}$ : There are no significant differences in the degree of impact between the categories of social status.

$\mathrm{H}_{1}$ : There are significant differences in the degree of impact between the categories of social status.

Based on the p output, we recommend not rejecting the alternative $\mathrm{H} 1$ hypothesis in all variables. In the category of the social status variable, there are differences that should be considered in marketing activities. Figure 6 visualizes the impact level.

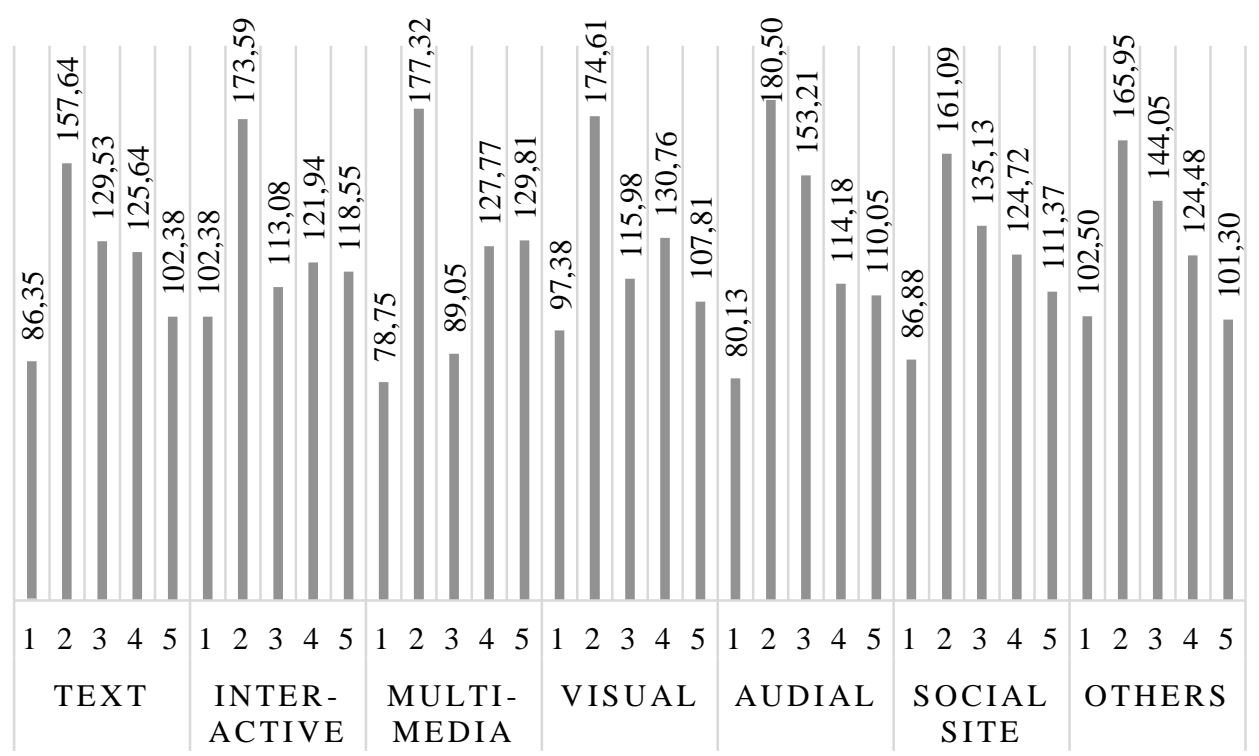

*1 - Unemployed, 2 - Pensioner, 3 - Entrepreneur, 4 - Student, 5 - Employee

Figure 6 - Forms of tools (Social status) - evaluation (own elaboration)

Analytically looking at the differences in social status categories, we can say that the differences were manifested in each form of the instrument. In almost all forms, the smallest impact was found among the unemployed and the highest among retirees. In "other" forms (RSS, etc.) the lowest impact was attributed to employees and to retirees with a slight difference.

Discussion. Personalization discussions are expanding in a number of ways, whether in social networking areas, as Tran (2017) claims, or in the areas of traditional marketing (McDarby et al. 2018). In the field of applied research, the expansion of the scientific horizon is important. It is particularly important from the point of view of the pivotal marketing pillar that Kotler and Keller (2012) characterized as meeting the customer's needs with an emphasis on profit. Janouch (2010) determines the tools and forms of online 
marketing but has not defined the differences in the perception among individual customer groups. Our contribution to this area is in the precise assessment of the preference and therefore of the output of the applications. It is a recommendation of specific tools for specific groups of potential and real customers.

Personalization is an activity optimization system to maximize customer satisfaction. Trends in this system are not significantly different in the geographical demarcation of the regions. Personalization is a systematic activity that is a global trend and it should not be underestimated.

The principle of personalization is embedded in a detailed understanding of the customer. Customer needs are satisfied when we know the customer. We know his/her product preferences, know his/her habits and, finally, yet importantly, we will recognize the communication tools and forms of the tools that most influence the customer. The principle of personalization in tool dimensions and forms of marketing communication tools offers us the opportunity to effectively communicate with the customer.

Based on the analyses of the previous section, we assume that not all customer groups respond proportionately to all tools and forms of marketing communication tools. This exact underlying argument is of utmost importance for the marketing activities in the online environment of primarily small and medium-sized businesses that do not have explicitly defined customer segments and ongoing analyses of previous campaigns. When placing a product on the market, smaller businesses do not usually have a marketing research budget that would reveal the "best of" to get closer to the customer. Often they do not have built efficient distribution routes to existing products and services. The differences in attributed influence reduce the randomness of the decision, in approaching the customer - personalization from the point of view of the communication strategy of the campaign. As we mentioned in the introduction, offering sales to meet customers' needs does not only affect the campaign through its communication substance but also the impact of other elements of the marketing mix and other influences, purchasing, trends, personal preferences, family etc. Through communication, we often try to convince the customer to see the product to meet his or her needs and offer an affordable price. Communication and personalization should also be given the appropriate attention. Delivering causality in communication as an indispensable part of the marketing mix represents a huge opportunity for the research area in a great deal with the real application of outputs in practice. We plan to enrich the personalization of communication in the context of new knowledge leading to customer benefits, business profits and to the shift in theory.

In the vast majority of cases, the creation of marketing activities focuses on the construction of segments based on assumptions in strong association with the product. Previous ideas offer a stronger view of the concept of marketing. These ideas look at the optimization of the campaign from the perspective of the customer. The main idea of the research was to demonstrate the different homogeneity of the perceived impact of communication tools in the online environment (advertising, sales promotion, events, PR activities, direct marketing) and tooling (text, interactive, multimedia, visual), second-degree grading of variables such as gender, education and social status. By implication, this view of personalization in campaigning should not be absent, especially for campaigns where there is a high percentage of uncertainty.

In hypotheses $\mathrm{H} 1 \mathrm{a}$ and $\mathrm{H} 2 \mathrm{a}$, we analysed the homogeneity of tools and their forms. For both variables, we recommend adopting an alternative hypothesis, meaning there are significant differences between the tools and forms of tools. Sales promotion, direct marketing and advertising are considered to be the best tools. Visual, multimedia and interactive forms are considered to be the most influential. The optimal tool in combination with its form is generally supported by sales in visual form. However, there were only slight differences between the above-mentioned tools and forms. Instruments and forms of tools that respondents do not assign as much were online events and PR in a combination of forms as auditing or others, i.e. RSS etc. In the second part, there were significant differences in many categories of the analysed variables (gender, education, social status). Based on the output, we can define the so-called problematic category - the unemployed, where the level of influence has not been measured in most 
instruments and forms of tools. The very grateful category in the social status, were retirees, with a high degree of influence in several instruments and forms of tools.

In these parts, we have explained the advantages of personalization in Slovakia, further research in this area could be carried out in terms of application and drawing an exact conclusion in the case of specific products and services. We experimentally prove the effects of personalization on particular products, for individual groups of customers, with an emphasis on the principles of a marketing concept.

Acknowledgement. This article is one of the partial outputs under the scientific research grant VEGA $1 / 0806 / 16$ „Research on issues of consumer behaviour of a new generation of customers with emphasis on identifying preferences and usability of mobile platforms in the process of e-commerce of the subjects localized predominantly on the Central European Market“ and VEGA 1/0789/17 „Research of e-commerce with relation to dominant marketing practices and important characteristics of consumer behavior while using mobile device platforms."

Bednarčik, Z. (2013). The importance of strategic marketing management in companies for an increase in theirs competitiveness. In: 16th International Colloquium on Regional Sciences. Brno: Masarykova univerzita, pp. 252-258.

Fernandez-Lanvin, D., Deandres-Suarez, J., Gonzales-Rodriguez, M., Pariente-Martinez, B. (2018). The dimension of age and gender as user model demographic factors for automatic personalization in e-commerce sites. Computer Standards \& Interfaces.

Foret, M. (2008). Marketing research - we know our customers (Marketingový prúzkum - poznávame svoje zákazníky). Brno: Computer Press. 124 p. 1st Edition.

Grancay, M., Grancay, N., Drutarovska, J., Mura, L. (2015). Gravity model of trade of the Czech and Slovak Republics 19952012: How have determinants of trade changed. Politicka Ekonomie, 63 (6), pp. 759-777.

Janouch, V. (2010). Internet Marketing: Enforce the web and social networks. (Internetový marketing: prosadte se na webu a sociálních sítích). Praha: Computer Press. 304 p. 1th Edition.

Kim, D., Ammeter, A. P. (2018). Shifts in online consumer behavior: A preliminary investigation of the net generation. Journal of Theoretical and Applied Electronic Commerce Research, 13(1), pp. 1-25.

Kotler, P., Armstrong, G. (2007). Marketing. Praha: Grada Publishing. 856 p. 6th Edition

Kotler, P., Keller, L. K. (2012). Marketing management. New Jersey: Pearson Education. 816 p. 14th edition.

Kwon, S., Ha. S., Kowal, Ch. (2017). How online self-customization creates identification: Antecedents and consequences of consumer-customized product identification and the role of product involvement. Computers in Human Behavior, 75, pp. 1-13.

Lee, E. J., Park, J. K. (2009). Online service personalization for apparel shopping. Journal of Retailing and Consumer Services, 16(2), pp. 83-91.

$\mathrm{Li}, \mathrm{C}$., Liu, J. (2017). A name alone is not enough: A reexamination of web-based personalization effect. Computers in Human Behavior, 72, pp. 132-139.

Matic, A., Pielot, M., Oliver, N. (2017). OMG! How did it know that?" Reactions to Highly-Personalized Ads. UMAP 2017 Adjunct Publication of the 25th Conference on User Modeling, Adaptation and Personalization, pp. 41-46.

McDarby, F., O'hora, D., Ośhea, D., Byrne, M. (2018). Aking the sweetness out of the "Share a Coke' marketing campaign: the influence of personalized labelling on elementary school children's bottled drink choices. Pediatric obesity, 13(1), pp. 63-69.

Mura, L., Machová, R., Tóth, Z. (2015). Evaluation of innovation performance of the business networks. Hradec Economic Days, 5(5), pp. 41-47.

Porter, M. (1985). Competitive advantage. The Academy of Management Review, 10(4), pp. 873-875.

Štefko, R., Fedorko, R., Bačík, R. (2014). The Significance of Internet Marketing Tools in Terms of Building a Positive Image of an Higher Education Institution. In: Crafting global competitive economies: 2020 Vision strategic planning \& smart implementation, Vols. I-IV, pp: 1764-1772.

Tran, T. P. (2017). Personalized ads on Facebook: An effective marketing tool for online marketers. Journal of Retailing and Consumer Services, 39, pp. 230-242.

Xu, H., ZOU, X., Wang, H. (2006). Consumers attitudes of e-commerce in china, Consumers attitudes of e-commerce in china, 7(2), pp. 201-207.

Xiao, Bo and Benbasat, Izak. (2011). Product-Related Deception in E-Commerce: A Theoretical Perspective, In: MIS Quarterly, 35: 1, pp.169-195.

Makris C., Siaterlis K. and Vikatos P. (2017). Personalized Hotlink Assignment using Social Networks. In Proceedings of the 13th International Conference on Web Information Systems and Technologies - Volume 1: WEBIST, pp. 71-79.

Sahni, N. S., Wheeler, S. Ch., Chintagunta, P. K., (2016). Personalization in Email Marketing: The Role of Non-Informative Advertising Content. Stanford University Graduate School of Business Research Paper No. 16-14. Available at SSRN: https://ssrn.com/abstract=2725251 or http://dx.doi.org/10.2139/ssrn.2725251.

Schwarzl, S., \& Grabowska, M. (2015). Online marketing strategies: the future is here. Journal of International Studies, 8(2), 
187-196.

Haim, M., Graefe, A., Brosius H., (2018). Burst of the Filter Bubble?, Effects of personalization on the diversity of Google News, In: Digital Journalism, 6:3, pp. 330-343.

Watróbski, J., Jankowski, J., Ziemba, P. (2016), Multistage Performance Modelling in Digital Marketing Management, Economics and Sociology, 9(2), 101-125. DOI: 10.14254/2071-789X.2016/9-2/7

Б. Гавурова, Ph.D., доцент, Технічний університет в Кошице (Кошице, Словаччина);

P. Бачик, Ph.D., доцент, Прешівський університет (Прешов, Словаччина);

P. Федорко, Ph.D., Прешівський університет (Прешов, Словаччина);

М. Рігельський, аспірант, Прешівський університет (Прешов, Словаччина).

Аналітичний огляд інструментарію онлайн-маркетингу для оптимізації персоналізованих маркетингових кампаній в Словаччині

Метою статті $є$ аналіз підходів до проведення персоналізованих маркетингових кампаній з метою їх оптимізаиії. Розелянуто та оцінено індивідуальне сприйняття споживачами маркетингових комунікаційних інструментів в онлайнсередовищі. Виявлено, що при плануванні персоналізованих маркетингових кампаній враховується як правило лише ставлення клієнта до продукту, що тим самим знижує ії ефективність. Авторами визначається місие персоналізації в проведенні маркетингових кампаній, яка розелядається як система пошуку конкретних інструментів максимізації рівня задоволеності клієнтів. В даному дослідженні запропоновано основні параметри оптимізації персоналізованих маркетингових кампаній. 3 метою перевірки гіпотез про однорідність вибірок маркетингових інструментів було використано статистичний аналіз з урахуванням змінних факторів: гендерної ознаки, освіти та соціального статусу. Ідентифікація залежних та незалежних змінних здійснювалась на основі результатів анкетування 244 респондентів Словаччини у 2017 році. Отримані результати мають практичний характер та сфокусовані на підвищенні ефрективності проведення маркетингової кампанії в онлайн-середовищі, в першу чергу для підприємств малого та середнього бізнесу, які не мають чітко розділеної на сегменти (кластери) клієнтської бази та обмежені у фінансових ресурсах. У рамках дослідження автори диверсифікували інструменти онлайн-маркетингу за ступенем їх впливу на клієнтів в залежності від рівня освіти, гендерної ознаки та соціального статусу. Автори зосереджують увагу на тому, що обмеженість використання отриманих результатів пояснюється їх чутливістю до змін цілей маркетингової кампанії та соціального устрою країни.

Ключові слова: маркетингові інструменти, форми маркетингових інструментів, персоналізація клієнтів, персоналізація маркетингових комунікацій, оптимізація маркетингової кампанії. 